Creative Commons User License: CC BY-NC-ND

Abstracted by: EBSCOhost, Electronic Journals Service (EJS),

Google Scholar, Journal Seek, Scientific Commons,

Food and Agricultural Organization (FAO), CABI and Scopus

http://eoi.citefactor.org/10.11226/v23i3
Journal of Agricultural Extension

Vol. 23 (3) July, 2019

ISSN(e): 24086851; ISSN(Print); 1119944X

http://journal.aesonnigeria.org

http://www.ajol.info/index.php/jae

Email: editorinchief@aesonnigeria.org

\title{
Off-Farm Economic Activities of Rural Women for Household Food Security in
}

Kaduna State, Nigeria https://dx.doi.org/10.4314/jae.v23i3.3

\section{Fadlullah Olayiwola ISSA}

National Agricultural Extension and Research Liaison Services

Ahmadu Bello University, Zaria, Nigeria

issafola@mail.com +2348033339312

\section{Abstract}

This study analysed the contribution of off-farm economic activities of rural women to household food security in Kaduna State, Nigeria. Specifically, this study identified offfarm activities with which rural women are engaged, and assessed their level of involvement in off-farm activities, assessed women's expenditure on household needs, determined the relationship between respondents' socio-economic characteristics and their off-farm activities, and identified women's constraints to engage in off-farm economic activities. One-hundred and eighty rural women used for this study were selected through multi-stage sampling techniques. Structured interview schedule was used to elicit relevant information from the respondents. Frequency counts, percentages, and chi-square test were used to analyse the data collected. The mean age, monthly income, and household size of the rural women was 46 years, $\# 8,879$, and 7 , respectively. Most of them (43.9\%) had no formal education. Most rural women engaged in multiple off-farm economic activities including trading, food processing, tailoring, livestock rearing amongst others. The majority (82.8\% and $72.8 \%$ ) of the women contributes to provide food and cloth, respectively, for the household. Significant relationship exists between household size $\left(X^{2}=2.87 ; P \leq 0.01\right)$, access to extension $\left(X^{2}=1.98 ; P \leq 0.01\right)$, and access to credit $\left(X^{2}=1.73 ; P \leq 0.01\right)$ and women engagement in off-farm activities. Also, women's contributions to household food security depend on a number of activities engaged in. Poor institutional support was the major constraint to engagement in rural off-farm economic activities. Extension agencies should design innovative ways (through training and re-training) to impact on the off-farm activities of women.

Keywords: Rural women, off-farm activities, food security, rural economy, Nigeria

\section{Introduction}

High incidence of hunger and malnutrition has been a major problem especially among rural dwellers in developing countries. Rural off-farm economic activities offer solutions to the problems of food insecurity, extreme poverty and poor livelihood among the rural populace. 
Creative Commons User License: CC BY-NC-ND

Abstracted by: EBSCOhost, Electronic Journals Service (EJS),

Google Scholar, Journal Seek, Scientific Commons,

Food and Agricultural Organization (FAO), CABI and Scopus

http://eoi.citefactor.org/10.11226/v23i3
Journal of Agricultural Extension

Vol. 23 (3) July, 2019

ISSN(e): 24086851; ISSN(Print); 1119944X

http://journal.aesonnigeria.org

http://www.ajol.info/index.php/jae

Email: editorinchief@aesonnigeria.org

The dwindling farm production and productivity (in the face of rising population) justifies the fact that agriculture does not have the capacity to provide sustainable food security and livelihood opportunities to rural households. The concomitant effects of environmental degradation, rapid population growth, slow spread of technology and low public investment in agriculture account for the increasing inability of the farm sector to sustain rural livelihoods (Dary and Kuunibe, 2012; Bernardin (2012). Michael and Tilman, 2017) asserted that the rural economy is not confined to the agricultural sector alone, but embraces all economic activities in rural areas. Equally, rural household food security is not limited to income derived solely from agriculture but may derive from diverse sources (Davis, 2006, Davie et al. 2017). Thus, non-farm economic activities (NFEAs) are part of a diversified livelihood portfolio among most rural people in developing and transitional economies (Davis et al. 2017).

With this background, dependence upon subsistence farming confronts households with a precarious living, exposing them to adverse contingencies (food insecurity) which propel them to engage in off-farm economic activities. Consequently, the economic activity of poorer people seeks to make them look for alternative sustenance rather than depending upon a single occupation (Ulubaşoğlu et al. 2014). In this paper, the rural off-farm economic activities (ROFEAs) are defined as all those activities associated with self-employment in incomegenerating activities that are not necessarily agricultural but located in the rural areas. Thus, rural off-farm activities include agro-processing, commodity trading, sale of household domestic materials, livestock rearing, sales of food and other small businesses. The definition of ROFEA is solely activity-based (self-employment) to generate income in order to ensure household food security.

A number of studies have shown that the rural non-farm sector is playing an important role not only in the rural but also in the national economy (Issa et al. 2015; Yakubu et al. 2015; Ibidapo et al. 2017). ROFEAs provides vital income diversification and access to cash at key moments especially in West Africa, where the risks of farming are high and rural savings, 
Creative Commons User License: CC BY-NC-ND

Abstracted by: EBSCOhost, Electronic Journals Service (EJS),

Google Scholar, Journal Seek, Scientific Commons,

Food and Agricultural Organization (FAO), CABI and Scopus

http://eoi.citefactor.org/10.11226/v23i3
Journal of Agricultural Extension

Vol. 23 (3) July, 2019

ISSN(e): 24086851; ISSN(Print); $1119944 X$

http://journal.aesonnigeria.org

http://www.ajol.info/index.php/jae

Email: editorinchief@aesonnigeria.org

credit and insurance mechanisms are poorly developed or not available (Adewunmi et al. 2013). Rural off-farm economic activities may among other things; absorb surplus labour in rural areas, help farm-based households spread risks, offer more remunerative activities to supplement or replace agricultural income, offer income potential during the agricultural offseason, and provide a means to cope or survive when farming fails (Loughrey et al.2017; Bezu and Holden, 2014; Davis et al., 2017; Adjognon et al. 2017). In terms of employment, Sheahan and Christopher (2014) believe that the share of the off-farm sector in rural employment in developing countries varies from $20 \%$ to $50 \%$. In terms of income, Davis et al., 2017 and Adjognon et al. 2017 found rural non-farm income shares in Africa to be ranging from $22 \%$ to $93 \%$ and Egyei and Adzoror (2013) agreed that $30-50 \%$ is common in subSaharan Africa. Haggblade et al. (2010) indicate that off-farm income accounts for between $35 \%$ and $50 \%$ of total income of rural households in developing countries. Davis et al. (2017) put the global figure at approximately $58 \%$, with some countries having a share as high as $75 \%$ of total income on average. The share of off-farm income is expected to increase substantially in the coming years, especially in sub-Saharan Africa where increasing population growth and limited agricultural resources are threatening the growth of the agricultural sector (Haggblade et al. 2017). Zereyesus et al. (2017) agreed that about $75 \%$ of farm households were engaged in off-farm activities in rural Ghana. The story is same even in the developed countries (Ibekwe et al. 2010). Fernandez-Cornejo (2007) and Ivanic and Martin (2017) reported about 65\% and $75 \%$ participation rate among United States and Taiwan farm households respectively.

Farm households' income is not sufficient even to feed their families. Most rural women engage in off-farm activities mainly to supplement their agricultural income. Excess labor in the family and the seasonality of agriculture are the other key factors responsible for farmers to engage in off-farm activities. The seasonality of agriculture causes a farm family to have excess labour during the slack season, which induces them to engage in other non-farm activities. Availability of off-farm opportunities also propels women to engage in them in order to boost household food security (Beyene, 2008; Kassa et al. 2017). 
Creative Commons User License: CC BY-NC-ND

Abstracted by: EBSCOhost, Electronic Journals Service (EJS),

Google Scholar, Journal Seek, Scientific Commons,

Food and Agricultural Organization (FAO), CABI and Scopus

http://eoi.citefactor.org/10.11226/v23i3
Journal of Agricultural Extension

Vol. 23 (3) July, 2019

ISSN(e): 24086851; ISSN(Print); 1119944X

http://journal.aesonnigeria.org

http://www.ajol.info/index.php/iae

Email: editorinchief@aesonnigeria.org

Since more than $85 \%$ of the total population of Nigeria is dependent on agriculture, the performance of the sector relies on the labor of both genders. Rural women provide a substantial contribution to agricultural production. In addition to farming and home activities, they also participate in non-farm activities (Scharf and Rahut, 2014; Kagbu and Issa, 2016). Females participate in both wage and self-employment. In addition, they are getting income by engaging in self-employment activities like weaving/spinning, making and selling fire wood.

The general objective of this research was to examine the contribution of off-farm economic activities of rural women to household food security in Kaduna State, Nigeria. The specific objectives were to identify off-farm sources by which rural women enhanced their livelihoods, assess women's involvement in off-farm activities; assess women's expenditure on household needs; determine the relationship between respondents' socio-economic characteristics and their engagement in off-farm activities, and identify women's constraints to engagement in offfarm economic activities.

\section{Methodology}

Kaduna State lies between longitude $06^{\prime} 00$ and $09^{\prime} 10^{\prime}$ East of the Greenwich Meridian between and latitudes $09^{0} 00$ and $11^{0} 30$ North of the Equator. It occupies an area of approximately 48,473.2 square kilometres (FOS, 2006). Agriculture accounts for an estimated 56 percent of Kaduna's GDP and employs approximately 4 million people. 
Creative Commons User License: CC BY-NC-ND

Abstracted by: EBSCOhost, Electronic Journals Service (EJS),

Google Scholar, Journal Seek, Scientific Commons,

Food and Agricultural Organization (FAO), CABI and Scopus

http://eoi.citefactor.org/10.11226/v23i3
Journal of Agricultural Extension

Vol. 23 (3) July, 2019

ISSN(e): 24086851; ISSN(Print); 1119944X

http://journal.aesonnigeria.org

http://www.ajol.info/index.php/iae

Email: editorinchief@aesonnigeria.org

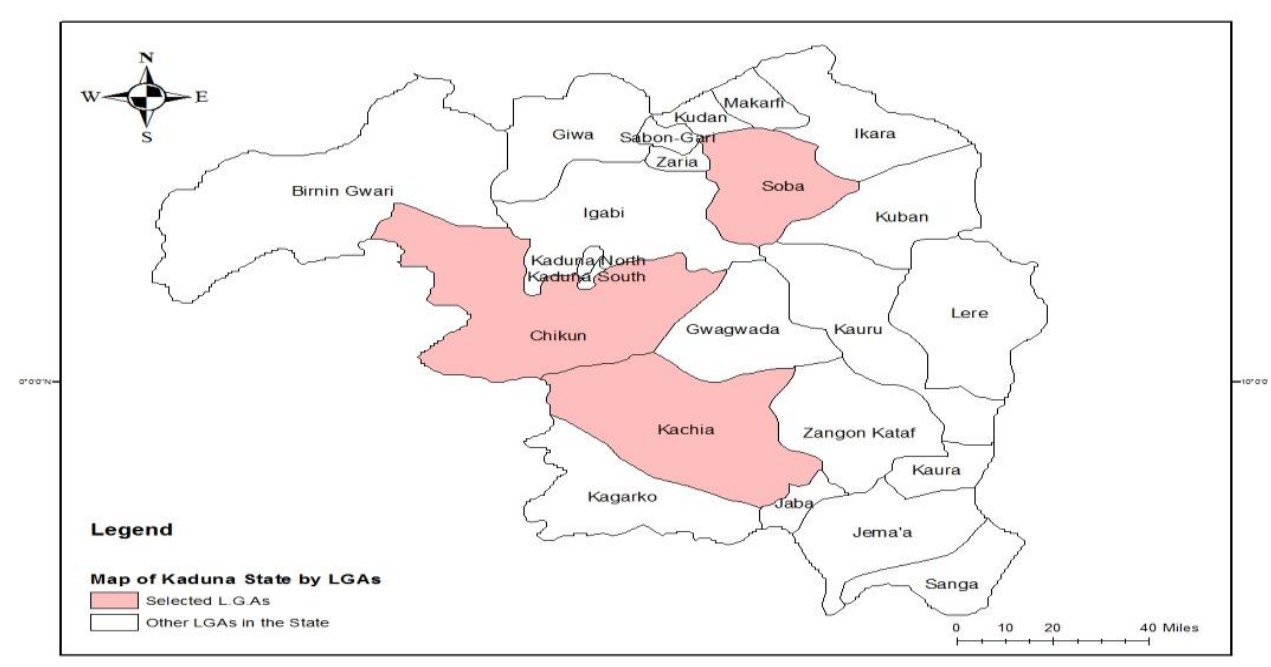

Figure 1: Map of Kaduna State showing study LGAs

Multi-stage sampling combining purposive, cluster, proportional and simple random sampling techniques was used to select respondents for this study. The first stage involved the random selection of three local government areas i.e. one LGA per senatorial district. Soba LGA (Kaduna North), Chikun LGA (Kaduna Central) and Kachia LGA (Kaduna South) were selected. The second stage involved the random selection of four communities from each LGA. A reconnaissance survey involving the purposive listing of 1,802 women who engaged in off-farm economic activities was conducted. Respondents were selected proportionally to the number of women listed in the communities. Clustering was carried out along selected Wards from each LGA. Selected Wards are Rido, Kuriga and Kanai (in Chikun LGA), Agunu, Gidan-Tagwai and Bishni (in Kachia LGA), and Gami-Gira, Dan-wata and Garu (in Soba LGA). In all, a total of 180 women (10\%) were used as sample for this study. Percentages and means were used to analyze the socio-economic characteristics of the women. The relationship between the selected socio-economic characteristics of women and their engagement in off-farm activities was established using chi-square procedure of SPSS (SPSS, 2010). Also, the relationship between women's engagement in off-farm activities and their contribution to household needs was established using chi-square. 
Creative Commons User License: CC BY-NC-ND

Abstracted by: EBSCOhost, Electronic Journals Service (EJS),

Google Scholar, Journal Seek, Scientific Commons,

Food and Agricultural Organization (FAO), CABI and Scopus

http://eoi.citefactor.org/10.11226/v23i3
Journal of Agricultural Extension

Vol. 23 (3) July, 2019

ISSN(e): 24086851; ISSN(Print); 1119944X

http://journal.aesonnigeria.org

http://www.ajol.info/index.php/jae

Email: editorinchief@aesonnigeria.org

Variables and measurement

Table 1: Measurement of selected variables

\begin{tabular}{|c|c|c|}
\hline Variables & Measurement & $\begin{array}{l}\text { Expected } \\
\text { Sign }\end{array}$ \\
\hline Age & Actual age of respondent in years & - \\
\hline Marital status & $1=$ single, $2=$ married, $3=$ divorced, $4=$ widowed & - \\
\hline $\begin{array}{l}\text { Income from off-farm } \\
\text { activities }\end{array}$ & $\begin{array}{l}\text { Actual amount earned from off-farm activities } \\
\text { per month }\end{array}$ & + \\
\hline Level of education & Highest educational qualification & + \\
\hline Household size & $\begin{array}{l}\text { Actual number of people feeding and living } \\
\text { together }\end{array}$ & \\
\hline Access to extension & $1=$ Yes, $0=$ No & + \\
\hline Access to credit & $1=$ Yes, $0=$ No & + \\
\hline $\begin{array}{l}\text { Membership } \\
\text { cooperative }\end{array}$ & $1=$ Yes, $0=$ No & + \\
\hline
\end{tabular}

\section{Results and Discussion}

\section{Socio-Economic Characteristics of Women}

Result in Table 2 indicates that the average age of rural women was 46 years. This indicates that women were in active age and possess the energy to engage in ROFEAs to ensure household food security. Meludu (2005) found similar result in Oyo State, Nigeria. Also, the majority $(62.8 \%)$ of the rural women were married. This implies that rural women are responsible, focused and are practically driven to engage in ROFEAs. An average household size of 7 people implies that most rural women had enough mouths to feed thereby necessitating regular engagement in off-farm activities to augment household farm income. Furthermore, above average (about $52 \%$ ) had no primary school certificate, while about $48 \%$ had one form of formal education or the other. This implies that the literacy level was below average. High level of literacy is expected to enhance women's ability to succeed in off-farm economic engagements. Average earning from off-farm economic activities was about $\$ 9,000$ per month. This amount is abysmally low considering the economic realities in Nigeria and especially with large household size. 
Creative Commons User License: CC BY-NC-ND

Abstracted by: EBSCOhost, Electronic Journals Service (EJS),

Google Scholar, Journal Seek, Scientific Commons,

Food and Agricultural Organization (FAO), CABI and Scopus

http://eoi.citefactor.org/10.11226/v23i3
Journal of Agricultural Extension

Vol. 23 (3) July, 2019

ISSN(e): 24086851; ISSN(Print); 1119944X

http://journal.aesonnigeria.org

http://www.ajol.info/index.php/jae

Email: editorinchief@aesonnigeria.org

Table 2: Socio-economic characteristics of women

\begin{tabular}{lrl}
\hline Socio-economic variables & Percentage & Mean \\
\hline Age & & 46 \\
$<30$ & 22.2 & \\
$30-39$ & 26.1 & \\
$40-49$ & 45.0 & \\
50 and above & 6.7 & \\
Marital status & & \\
Single & 7.8 & \\
Married & 62.8 & \\
Divorced & 17.2 & $\mathbf{8 , 8 7 9}$ \\
Widowed & 12.2 & \\
Income (Monthly) (\$) & & \\
s5000 & 16.1 & \\
$5001-10000$ & 52.2 & \\
10001 - 15000 & 23.9 & \\
$15001-20000$ & 6.1 & \\
$>20000$ & 1.7 & \\
Level of education & & \\
No formal education & 43.9 & \\
Adult education & 8.3 & \\
Primary & 23.3 & \\
Secondary & 18.9 & \\
Post-secondary & 5.6 & \\
Household size & & \\
1 - 4 & 21.1 & \\
$5-8$ & 60.0 & \\
$>8$ & 18.9 & \\
\hline
\end{tabular}

\section{Women's Off-farm engagements}

Figure 2 indicates the various off-farm activities engaged in by rural women. The majority $(96.7 \%)$, were engaged in labour for grain processing, livestock (sheep, goat and local chicken) rearing (92.8\%) sales of locally brewed drinks (such as zobo, kunu and ginger drinks) (73.3\%), and sales of cooked/fried food (such as baked beans, masa, rice, beans, groundnut, tuwo, fried yam, fried fish, roasted maize) $(68.9 \%)$. Only few (10\%) of the studied women sells drinking water. It was found that most women engaged in multiple ROFEAs. Dary and Kuunibe, (2012) found that engagement in off-farms activities is widespread in Ghana. Similarly, Babatunde and Leliveld, (2012) found similar result in Kwara State, Nigeria. 
Creative Commons User License: CC BY-NC-ND

Abstracted by: EBSCOhost, Electronic Journals Service (EJS),

Google Scholar, Journal Seek, Scientific Commons,

Food and Agricultural Organization (FAO), CABI and Scopus

http://eoi.citefactor.org/10.11226/v23i3
Journal of Agricultural Extension

Vol. 23 (3) July, 2019

ISSN(e): 24086851; ISSN(Print); 1119944X

http://journal.aesonnigeria.org

http://www.ajol.info/index.php/jae

Email: editorinchief@aesonnigeria.org

Engagement in multiple ROFEAs is very likely to be connected to the fact that most of the activities are seasonal in nature. The relatively large household size (Table 2) could also be a push factor for women to engage in multiple activities in order to maximize profits to cushion the effects of hard times.

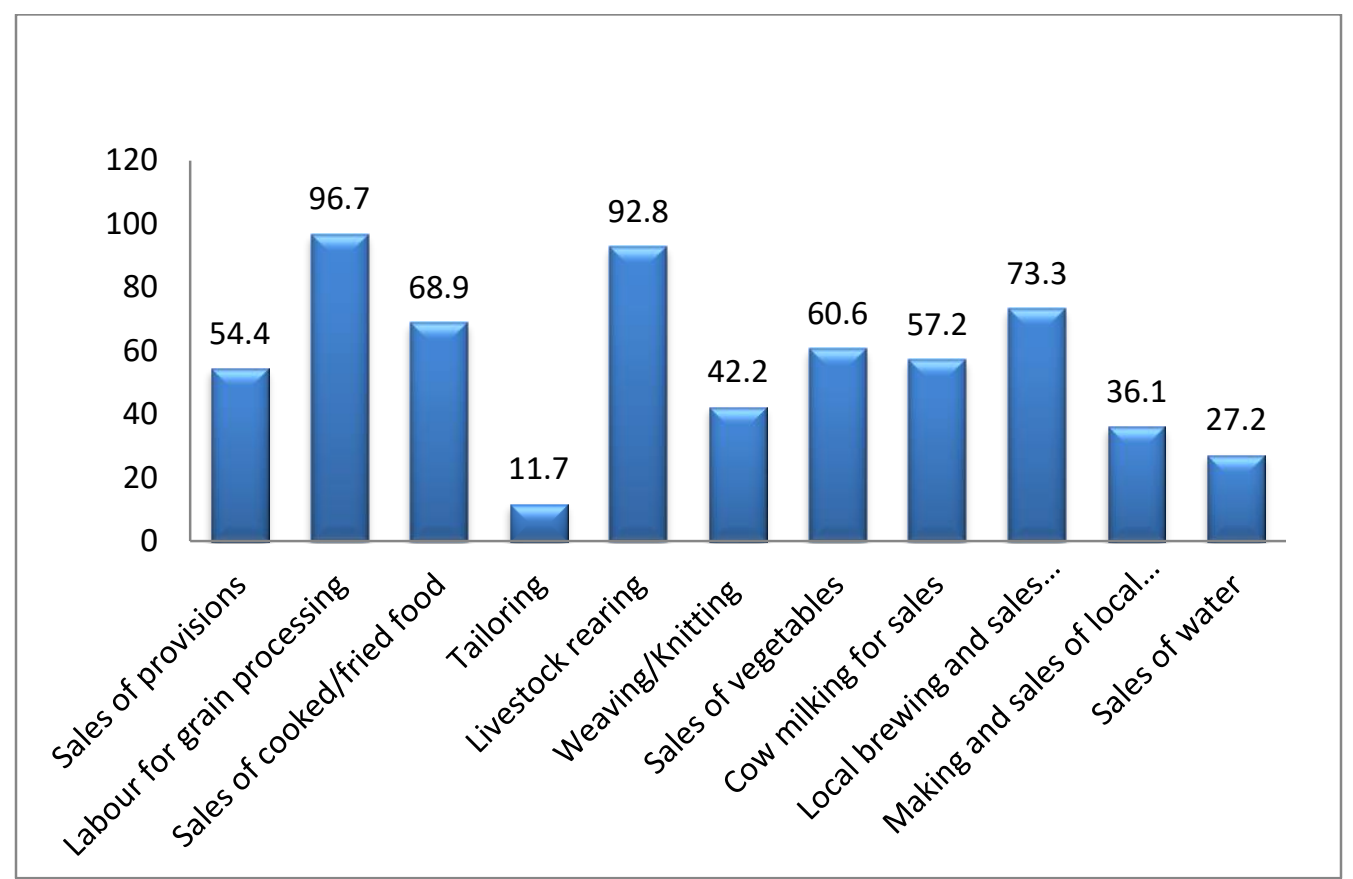

Figure 2: Distribution of women according to Off-farm engagements*

${ }^{*}$ Multiple responses indicated

\section{Rural Women's Contributions to Household Needs}

Rural women spend their income on various household needs as contribution to assist the family (Figure 3 ). The majority ( $82.8 \%$ and $72.8 \%$ ) of the women contribute to provide food and cloth, respectively, for the household. This implies that women were very concerned with the basic needs of life. Though majority $(>74 \%)$ of the women had below secondary level education (as depicted in Table 2), 60\% of them spends their income on the education needs of the family implying that education is important to them. Generally, women spend their income on all the household needs. 
Creative Commons User License: CC BY-NC-ND

Abstracted by: EBSCOhost, Electronic Journals Service (EJS),

Google Scholar, Journal Seek, Scientific Commons,

Food and Agricultural Organization (FAO), CABI and Scopus

http://eoi.citefactor.org/10.11226/v23i3
Journal of Agricultural Extension

Vol. 23 (3) July, 2019

ISSN(e): 24086851; ISSN(Print); 1119944X

http://journal.aesonnigeria.org

http://www.ajol.info/index.php/jae

Email: editorinchief@aesonnigeria.org

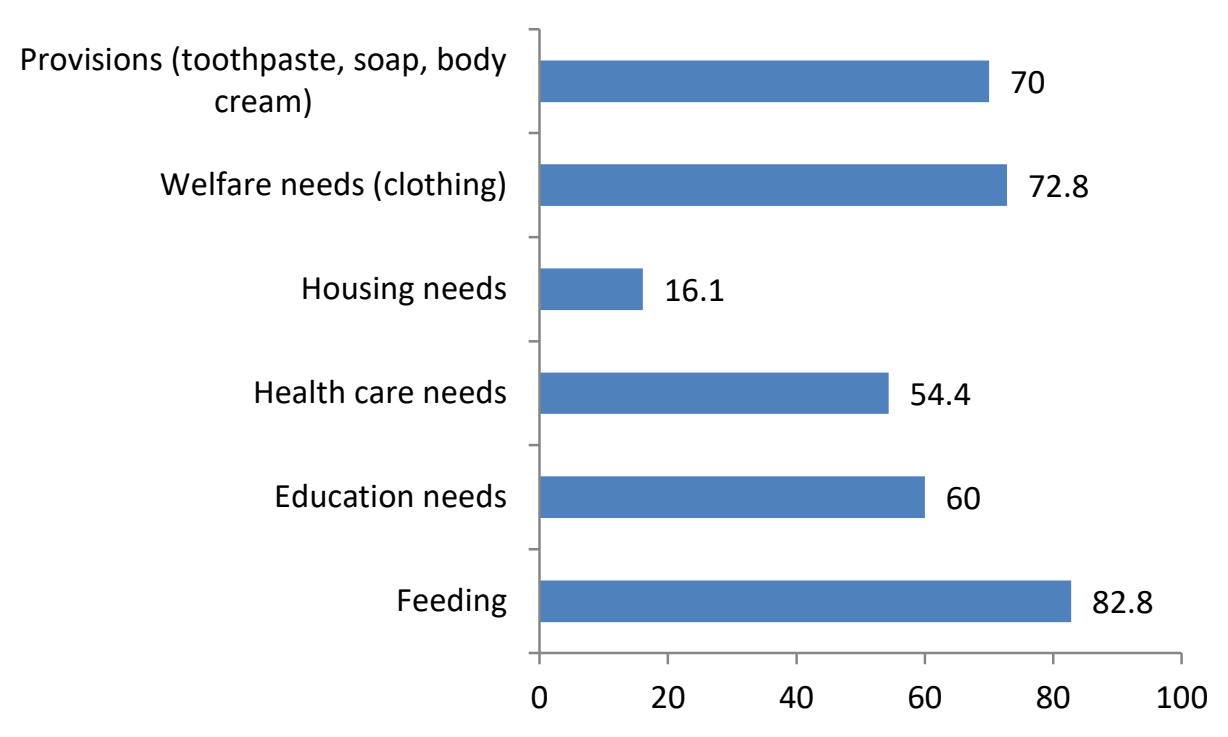

Figure 3: Distribution of women based on expenditure/contribution to household needs*

${ }^{*}$ Multiple responses indicated

\section{Dependence of Women's Engagement in ROFEAS on Socio-Economic Characteristics and Institutional Variables}

Selected socio-economic characteristics and institutional variables were tested as factors determining women's engagement in ROFEAs. Result in Table 3 indicates that household size ( $\left.X^{2}=2.87 ; \mathrm{P} \leq 0.05\right)$, access to extension $\left(X^{2}=1.98 ; \mathrm{P} \leq 0.05\right)$, and access to credit $\left(X^{2}=1.73\right.$; $\mathrm{P} \leq 0.05)$ were significant at 95\% level. Determine women's engagement in ROFEAs. Large household size indicates availability of labour for ROFEAs. It implies that respondents with large family size have high probability of engaging in RFOEAs. However, this contrasts the finding of Awotide et al. (2010) on rural livelihood diversification among farming households that increase in family size increases the probability of farmers being poor. Also, access to extension services especially women-in-agriculture agents is capable of increasing the number of opportunities for small scale businesses (such as preparation of cosmetics, brewing of local drinks and preparation of confectionaries) as well as enhance women's skill in engaging in such activities. The result implies that, the higher the women access to 
Creative Commons User License: CC BY-NC-ND

Abstracted by: EBSCOhost, Electronic Journals Service (EJS),

Google Scholar, Journal Seek, Scientific Commons,

Food and Agricultural Organization (FAO), CABI and Scopus

http://eoi.citefactor.org/10.11226/v23i3
Journal of Agricultural Extension

Vol. 23 (3) July, 2019

ISSN(e): 24086851; ISSN(Print); 1119944X

http://journal.aesonnigeria.org

http://www.ajol.info/index.php/iae

Email: editorinchief@aesonnigeria.org

extension; the higher the probability of engaging in RFOEAs. Furthermore, access to credit makes it possible for women to find better opportunity to either start a business or expand existing activities. This result implies that the more the women have access to credit; the more the likelihood of engaging in RFOEAs.

Table 3: Determinants of women's engagement in ROFEAs

\begin{tabular}{lll}
\hline Variables & Chi Square & Df \\
\hline Age & 4.63 & 5 \\
Marital status & 3.17 & 4 \\
Income & 3.75 & 6 \\
Level of education & 3.92 & 6 \\
Household size & $2.87^{\star}$ & 4 \\
Access to extension services & $1.98^{*}$ & 2 \\
Access to credit & $1.73^{*}$ & 2 \\
Membership of cooperatives & 1.68 & 2 \\
\hline
\end{tabular}

${ }^{*}$ Significant at $\mathrm{P} \leq 0.05$

\section{Dependence of Women's Contributions to Household Food Security on Engagement in ROFEAS}

As shown in Table 4, women's contributions to household food security depend on a number of activities engaged in. These include sales of provisions $\left(X^{2}=2.37 ; \mathrm{P} \leq 0.05\right)$ sales of cooked/fried food $\left(X^{2}=1.72 ; \mathrm{P} \leq 0.05\right)$, tailoring $\left(X^{2}=2.26 ; \mathrm{P} \leq 0.05\right)$ livestock rearing $\left(X^{2}=2.52\right.$; $P \leq 0.05)$, sales of vegetables $\left(X^{2}=21.62 ; P \leq 0.05\right)$ sales of locally brewed drinks $\left(X^{2}=2.19\right.$; $P \leq 0.05)$ and sales of locally made cosmetics $\left(X^{2}=2.24 ; P \leq 0.05\right)$. This implies that most of the respondents derived their source of livelihood from various means. According to Rijkers and Costa (2012) and Ajayi et al. (2016), diversification of income sources by rural households is norms for individuals or households for different socio-economic reasons. 
Creative Commons User License: CC BY-NC-ND

Abstracted by: EBSCOhost, Electronic Journals Service (EJS),

Google Scholar, Journal Seek, Scientific Commons,

Food and Agricultural Organization (FAO), CABI and Scopus

http://eoi.citefactor.org/10.11226/v23i3
Journal of Agricultural Extension

Vol. 23 (3) July, 2019

ISSN(e): 24086851; ISSN(Print); 1119944X

http://journal.aesonnigeria.org

http://www.ajol.info/index.php/jae

Email: editorinchief@aesonnigeria.org

Table 4: Relationship between women's engagement in off-farm activities and contributions to household food security

\begin{tabular}{lll}
\hline Women's engagement in off-farm activities & $\mathbf{X}^{2}$ & $\mathbf{D f}$ \\
\hline Sales of provisions & $2.37^{*}$ & 2 \\
Food processing (grains) & 5.26 & 3 \\
Sales of cooked/fried food & $1.72^{*}$ & 4 \\
Tailoring & $2.26^{*}$ & 2 \\
Livestock rearing & $2.52^{*}$ & 2 \\
Weaving/Knitting & 4.98 & 2 \\
Sales of vegetables & $1.62^{*}$ & 3 \\
Cow milking for sales & 4.77 & 2 \\
Sales of locally brewed drinks (Zobo, kunu and ginger drinks) & $2.19^{*}$ & 3 \\
Sales of locally made cosmetics (pomade, soap) & $2.24^{*}$ & 4 \\
Sales of water & $4.83^{*}$ & 2 \\
\hline
\end{tabular}

${ }^{*}$ Significant at $\mathrm{P} \leq 0.05$

\section{Women's Constraints to Engagement in Off-Farm Economic Activities}

Result in Table 5 revealed that women's engagement in ROFEAs is constrained by inadequate institutional supports such as inadequate training $(\bar{x}=3.25)$, poor infrastructure $(\bar{x}=3.09)$ and poor access to micro-credit $(\bar{x}=2.96)$, all of which were perceived as serious constraints to engagement in ROFEAs. Kagbu and Issa (2015) found that institutional factors were major constraints to women involvement in agribusiness. Extension training is supposed to sharpen the entrepreneurial skill of women so as to perform efficiently in any economic activities. Also, women engagement in RFOEAs has been limited by the poor infrastructural facilities. The poor extension service delivery orchestrated by the poor funding of the ADPs across Nigeria could have been responsible for the inadequate training being experienced among women.

Table 5: Ranking Women's constraints to engagement in off-farm economic activities

\begin{tabular}{lll}
\hline Women's Constraints & Sum total & Weighted Mean \\
\hline Inadequate extension training & 585 & $3.25^{\star}$ \\
Inadequate infrastructure & 556 & $3.09^{*}$ \\
Poor access to credit & 532 & $2.96^{*}$ \\
Inadequate finance & 520 & $2.89^{\star}$ \\
\hline
\end{tabular}

${ }^{*}=$ serious 
Creative Commons User License: CC BY-NC-ND

Abstracted by: EBSCOhost, Electronic Journals Service (EJS),

Google Scholar, Journal Seek, Scientific Commons,

Food and Agricultural Organization (FAO), CABI and Scopus

http://eoi.citefactor.org/10.11226/v23i3
Journal of Agricultural Extension

Vol. 23 (3) July, 2019

ISSN(e): 24086851; ISSN(Print); 1119944X

http://journal.aesonnigeria.org

http://www.ajol.info/index.php/jae

Email: editorinchief@aesonnigeria.org

\section{Conclusion and Recommendations}

Rural women are not only engaged, but highly involved in multiple off-farm economic activities for household survival. Women spend their earnings from off-farm economic activities to provide household needs. Household size, access to extension, and access to credit were determinants of women's engagement in ROFEAs. Constraints to women engagement in offfarm economic activities were majorly institutional. The scope extension training (especially by women-in -agriculture (WIA) agents) should be broadened to cater for the needs of women's off-farm engagements. Policy incentives such as micro-credit should be made to encourage the growth of off-farm economic activities by rural women.

\section{References}

Adewunmi, I.O., Ojiako, I. A. and Omotoyole, A. I. (2013). Participation and wage of rural female headed households in Nigeria non-farm employment European Scientific Journal (9)13:194-219.

Adjognon, G. S., Liverpool-Tasie, L. S. O., Benfica, R. M., and de la Fuente, A. (2017). Rural non-farm employment and household welfare: evidence from Malawi. World Bank Policy Research Working Paper No. 8096: 66.

Ajayi, O. J., Sanusi, O., Muhammed, Y. and Tsado, J. H (2016). Livelihood diversification of rural household in Niger State, Nigeria. Nigerian Journal of Agriculture, Food and Environment, 12(2): 156-161

Babatunde, R. O. and Leliveld, A. (2012). On-farm and Off-farm works: Complements or Substitutes? Evidence from rural Nigeria pp 1-41.

Bernardin, S. (2012). Non-farm income diversification in rural Ghana: Patterns and determinants. African Development Review, 24(3): 233-244.

Beyene, A. D. (2008). Determinants of off-farm participation decision of farm households in Ethiopia. Agrekon, 47(1): 140-161.

Bezu, S., and Holden, S. (2014). Are rural youth in Ethiopia abandoning agriculture? World Development, 64, 259-272.

Dary, S. K. and Kuunibe, N. (2012). Participation in rural non-farm economic activities in Ghana. American International Journal of Contemporary Research, 2(8): 154-161.

Davis, B., Winters. P., Reardon, T., and Stamoulis, K. (2017). Rural nonfarm employment and farming: household-level linkages. Agricultural Economics, 40(2), 119-123.

Dillon, B., Barrett, Christopher, B. (2017). Ten striking facts about agricultural input use in SubSaharan Africa, Food Policy, 67 (2017) 12-25

Egyei, R. K., and Adzoror, H.Y. (2013). Household Non-Farm Income: Any Influence on Agricultural Productivity in Rural Ghana? Developing Country Studies, 3 (9): 79-90 
Creative Commons User License: CC BY-NC-ND

Abstracted by: EBSCOhost, Electronic Journals Service (EJS),

Google Scholar, Journal Seek, Scientific Commons,

Food and Agricultural Organization (FAO), CABI and Scopus

http://eoi.citefactor.org/10.11226/v23i3
Journal of Agricultural Extension

Vol. 23 (3) July, 2019

ISSN(e): 24086851; ISSN(Print); 1119944X

http://journal.aesonnigeria.org

http://www.ajol.info/index.php/jae

Email: editorinchief@aesonnigeria.org

Fernandez-Cornejo, J. (2007). Off-farm income, technology adoption and farm economic performance. Economic Research Report No. ERR-36, Economic Research Service, U.S. Department of Agriculture, Washington, D.C.

Haggblade, S., Hazell, P. and Reardon, T. (2010). The rural non-farm economy: Prospects for growth and poverty reduction. World Development, 38(10): 1429-1441

Haggblade, S., Smale, M., Theriault, V., and Assima, A. (2017). Causes and consequences of increasing herbicide use in Mali. The European Journal of Development Research, 1 - 27.

Himelein, K. (2013). Calculations for Panel Surveys with Sub-Sampling and Split-off Tracking. Policy Research Working Paper 6373 IFAD (International Fund for Agricultural Development). (2016). Rural Development Report 2016. Retrieved from https://www.ifad.org/ruraldevelopmentreport

Ibekwe, U.C., Eze C.C., Ohajianya, D.O., Orebiyi, J.S., Onyemauwa, C.S. \& Korie, O.C. (2010). Determinants of non-farm income among farm households in South East Nigeria. Researcher, Academia Arena, 2(7): 1-4.

Ibidapo, I., Oso, O. and Ogunsipe. M. H. (2017). Contributions of non-farm activities in combating unemployment in rural areas of Ondo-East Local Government Area of Ondo state, Nigeria. Greener Journal of Agricultural Sciences, 7(7):175-181.

Issa, F. O., Tologbonse, E. B., Olaleye, R., Tologbonse, O. M. and Kagbu, J. H. (2015). Farmers' perception of climate change and coping strategies across gender in two Agroecological Zones of Nigeria. Journal of Agricultural Extension, 19(1): 23-37. Available at: http://dx.doi.org/10.4314.jae.v19i1.3

Ivanic, M., and Martin, W. (2017) Sectoral productivity growth and poverty reduction: National and global impacts. World development

Kagbu, J. H. and Issa, F. O. (2015). Assessment of women agribusiness cooperatives in Oyo State, Nigeria. International Journal of Agricultural Science, Research and Technology in Extension and Education Systems (IJASRT in EESs), 5(1) 19-27. Available @ http://ijasrt.iau-shoushtar.ac.ir/volume 111699.html

Kagbu, J. H. and Issa, F. O. (2016). Institutional factors influencing adoption of recommended rice production practices by women farmers in Nasarawa State. Accepted for publication Proceedings of the $21^{\text {st }}$ Annual Conference of Agricultural Extension Society of Nigeria (AESON) held at University of Ibadan, between 17th and 20th April. Pp 370281.

Kassa, B., Kassa, B., and Aregawi, K. (2017). Off-farm participation decision and its impact on crop yield in Northern Ethiopia, Journal of Development and Agricultural Economics, 9 (2) $16-25$

Loughrey, J and Knapp, E. (2017). The single farm payment and income risk in Irish farms 2005-2013. Agricultural and Food Economics, 5(1), 9.

Meludu, N. T. (2005). Contributions of off-farm economic activities of rural women to household food security in Ona-Ara area of Oyo State. Bowen Journal of Agriculture, 2(2): 134-142. 
Creative Commons User License: CC BY-NC-ND

Abstracted by: EBSCOhost, Electronic Journals Service (EJS),

Google Scholar, Journal Seek, Scientific Commons,

Food and Agricultural Organization (FAO), CABI and Scopus

http://eoi.citefactor.org/10.11226/v23i3
Journal of Agricultural Extension

Vol. 23 (3) July, 2019

ISSN(e): 24086851; ISSN(Print); 1119944X

http://journal.aesonnigeria.org

http://www.ajol.info/index.php/jae

Email: editorinchief@aesonnigeria.org

Michael C., and Tilman, D. (2017). Comparative analysis of environmental impacts of agricultural production systems, agricultural input efficiency, and food choice. Environmental Research Letters 12(6)

Rijkers, B., and Costa, R., 2012. Gender and rural non-farm entrepreneurship. World Develop, 40 (12), 2411-2426.

Scharf, M. M., and Rahut, D. B. (2014). Nonfarm employment and rural welfare: evidence from the Himalayas. American Journal of Agricultural Economics, 96(4): 1183-1197.

Sheahan, M., B., and Christopher, B., (2014). Understanding the Agricultural Input Landscape in Sub-Saharan Africa: Recent Plot, Household, and Community- Level Evidence. World Bank Policy Research Working Paper No. 7014.

Ulubaşoğlu, M. A., Hoang, T. X., and Pham, C. S. (2014). Non-farm activity, household expenditure, and poverty reduction in rural Vietnam: 2002-2008. World Development, 64, 554-568.

Wang, H., Yang, J., Jin, S., Chen,K., Riedinger, J., and Peng, C. (2015). Migration, Local Offfarm Employment, and Agricultural Production Efficiency: Evidence from China, Journal of Productivity Analysis, 2(2015): 24-40

World Bank, 2016. World Development Indicators, The World Bank, Washington DC, USA

Yakubu, B., Bulama, S. M., James, H. L. (2015) Off farm activities and its contribution to household income in Hawul Local Government Area, Borno State, Nigeria. IOSR Journal of Agriculture and Veterinary Science (IOSR-JAVS) 8(10) Ver. I , Pp 09-13.

Zereyesus, Y. A., Embaye, W. T., Tsiboe, F., and Amanor-Boadu, V. (2017). Implications of Non-Farm Work to Vulnerability to Food Poverty-Recent Evidence From Northern Ghana, World Development, 91, 113-124. 